\title{
Danish farmers' perception of water quality, nutrient reduction measures and their implementation strategy
}

\author{
F. G. Gachango, L. M. Andersen \& S. M. Pedersen \\ Institute of Food and Resource Economics, \\ Copenhagen University, Denmark
}

\begin{abstract}
Implementation of voluntary nutrient reduction technologies among Danish farms is relatively low despite the introduction of a number of incentives on such technologies. With data from 267 farmers, this study analyzed the level of uptake of these technologies and the farmers' perception of water quality, existing regulatory measures and their implementation strategies. In general, farmers perceived; the water quality to be above average and indicated a strong nonsupport for penalties on non-compliance. Results of two ordered probit models on adoption and perception showed a significant importance of factors such as farm and soil types, farm size and slopes and information availability. These findings give a direction to policy makers and other stakeholders on the need to increase information dissemination on; water quality requirements both at national and regional levels and availability and procedures of financial, technical and institutional support for the existing and future incentives. Ultimately, tailor-made incentives could be designed based on farm structure and physical characteristics so as to improve the pace of adoption of the technologies thereby reducing water pollution from farms substantially.

Keywords: agricultural water pollution, Denmark, agri-environmental measures, recipient water bodies, ordered probit.
\end{abstract}




\section{Introduction}

\subsection{Nutrient reduction plans}

For over the last 25 years, Denmark has implemented different approaches towards reduction of nitrogen and phosphorous discharges from agricultural farms. These initiatives range from the initial Action Plan for Aquatic Environment (APAE) in 1987 to the broader Green Growth Agreement (GGA) in 2009. The initiatives have mainly been implemented in a territorial approach as opposed to the designation of vulnerable zones adopted in other EU countries [1], with former initiatives being compulsory most of the latter initiatives being voluntary. The first APEA, effective in 1987 was followed shortly by APAE II, which was effected in 1998 with an aim of reducing Nitrogen and Phosphorus losses to aquatic environment by $50 \%$ and $80 \%$ respectively. The third APAE became effective in 2004 targeting further $\mathrm{N}$ and $\mathrm{P}$ reduction by $13 \%$ and $50 \%$, respectively by 2015 .

In 2009, the GGA (2009-2015) was launched. This was aimed at integrating activities in the implementation of the Water Framework Directive, dealing with the problems encountered in APAE III and ensuring a balance between nature, environment and agricultural development. The targets under the GGA are reduction of 19,000 tonnes of nitrogen to coastal water and 210 tonnes of phosphorous [2].

The initiatives under the GGA include government-supported interventions on biogas production, perennial crop production, organic production and implementation of wetlands. However, the compulsory nutrients pollution reduction measures developed in the previous action plans are still effective. Despite the incentives given under the GGA, the adoption and implementation of the proposed measures has been relatively low [3-5] a phenomenon worth investigation.

In the current Danish context, constructed wetlands are seen as a more targeted and cost effective option in the reduction of $\mathrm{N}$ and $\mathrm{P}$ pollution from agricultural fields [6]. Consequently, given the expected level of the technology's potential and the projected capacity of one hectare of wetland to remove $480-1380 \mathrm{Kg} \mathrm{N}$ per year [7] this measure if properly implemented could effectively reduce agricultural non-point water pollution. To establish the best strategy that policy makers could adopt in the implementation of constructed wetlands as a nutrient reduction measure, it is paramount to first establish the farmers' level of adoption of voluntary technologies, their attitudes and perception on the current surface water quality, the perceived impacts of the existing regulatory nutrients mitigation measures and their preferred mode of implementation of the pollution reduction measures. The objective of this paper is to investigate the four aspects and assess the relations among them.

\subsection{Previous studies and conceptual model}

Studies on farmers' perception of water quality and pollution reduction measures and adoption of associated BMPs have been conducted over the last few decades 
with most of these studies conducted in the US [8-11]. Bratt [12], analyzes the Swedish farmers' choices for management practices aimed at reducing nutrient pollution at a catchment level, while Sang [13], studies farmers' preference for catchment management practices in Scotland. These two studies have focused on catchment level analysis whereas others have primarily targeted areas designated as Nitrate Vulnerable Zones (NVZs) [14, 15].

In Denmark, only a few studies on farmers' perceptions on water quality and pollution reduction measures have been conducted $[1,16,17]$. Although the first study deals with a broader issue, producers' perspectives are not clearly captured since farmers do not form part of the respondents. The other two studies incorporate the farmers' perspectives but cover a single locality and pesticide pollution respectively. The current study however focuses on nutrients pollution and targets farmers within different catchment areas.

Different approaches have been used in perception and adoption studies. Adoptions of conservation technologies have mainly been based on the initial work of Ervin and Ervin [18], and Just and Zilberman [19], which base adoption on the expected utility. More studies have followed over the years and summaries of factors influencing adoption reported by Kabii and Horwitz [20] and Knowler and Bradshaw [21]. Behavioural approaches based on the theory of reasoned action and theory of planned behaviour $[22,23]$ have also been employed in many studies [24]. The current study follows the conceptual framework on the decision making process in the adoption of agricultural technologies [18]. The framework covers both adoption and perception aspects.

\section{Materials and methods}

\subsection{Data}

The survey data was collected between March and June 2013 among Danish farmers in Funen, Jutland and Zealand using an online questionnaire. A total of 626 farmers accessed the questionnaire link and responses were received from 368 farmers of which 267 were dully completed.

Utilizing complete cases data, the analysis was conducted in two stages; Initial descriptive analysis of the general respondents' perception on water quality, attitudes on effects of pollution reduction measures and the preferred mode of nutrients mitigation measures implementation strategies. Secondly, the factors influencing the farmers' adoption of voluntary nutrient reduction measures and their perception of water quality were analyzed by fitting the models presented under the model specification section.

\subsection{Model specification}

Two sets of equations are specified to represent the perception and the adoption stages. It is anticipated that the formation of farmers perception might be been influenced by their level of adoption of voluntary technologies. Farmers with voluntary implemented technologies would therefore be expected to perceive the 
water quality being high and vice versa. The equations representing the current adoption

$$
Y_{1 i}^{*}=\sum \beta_{j} X_{j i}+\varepsilon_{1 i}, \quad i=1,2 \ldots \ldots n
$$

and perception

$$
Y_{2 i}{ }^{*}=\sum \beta_{j} X_{j i}+Y_{i}^{*} Y_{i}+\varepsilon_{2 i}, \quad \mathrm{i}=1,2 \ldots \ldots \mathrm{n}
$$

where $Y_{1 i}{ }^{*}$ and $Y_{2 i}{ }^{*}$ are unobserved but what we observe is a form of censoring such that

$$
Y_{j}\left\{\begin{array}{c}
0 \text { if } Y_{j i}{ }^{*} \leq \mu_{j 1} \\
1 \text { if } \mu_{11}<Y_{j i}{ }^{*} \leq \mu_{j 2}, \\
\ldots \ldots \ldots \ldots \ldots \\
\text { j } \text { if } \mu_{j j}<Y_{j i}{ }^{*}
\end{array}\right.
$$

$X^{\prime}{ }_{j i}$ 's are vectors of the observed explanatory variables, $\beta_{j}$ 's are the parameters to be estimated corresponding to the $X$ ' $\mathrm{s}, \varepsilon_{1 i}$ and $\varepsilon_{2 i}$ are error terms (assumed to be normally distributed, $\mathrm{N}(0,1))$, the $\mu$ 's are the unknown threshold parameters and $Y_{i}^{*} Y_{i}$ are the predicted probabilities obtained from the adoption model estimation [25].

The first equation is specified as an ordered probit with the dependent variable (Techadopt). This variable takes three possible values indicating the number of voluntary technologies already adopted by the farmer such that: $0=$ none, $1=$ one, $2=$ more than one.

The second equation is also estimated as specified as an ordered probit with the dependent variable "perceived water quality" (Wqltypercp) taking 4 possible in an ordinal format; 1 = low, $2=$ moderate, $3=$ good and $4=$ very good. Due to the low frequency of "none" and "low" categories in the original dataset, the observations in the two groups are aggregated to "low" category). The choice of independent variables is based on the perception and adoption literature and are broadly classified into four; physical, personal and attitudinal, economic and institutional factors (Appendix 1).

\section{Results and discussion}

\subsection{Descriptive results}

The average age of the respondents in the study is 51years whereas the average farm size is 143 hectares. The average distance of the surveyed farms from their nearest recipient water bodies is $14 \mathrm{~km}$ with approximately $67 \%$ of the farms being within this distance. The sample statistics on the different farm types are in line with those of the population with over $90 \%$ of the respondents being involved in crop production. Organic and full time farmers accounts for $9 \%$ and $72 \%$ of the respondents respectively. On the soil types, approximately $50 \%$ of the respondents indicate having proportions of sand soils in their farms while $70 \%, 35 \%$ and $25 \%$ 
indicate the presence of clayey-sand sandy-clay and heavy-clay soils, respectively. Medium farm slopes (6-12 degrees) are reported by majority of the respondents at $56 \%$.

A summary on adoption and implementation of nutrients reduction technologies indicate a current employment of one or more technologies by $65 \%$ of the respondents. Natural wetlands, permanent grass cultivation and precision farming technologies are the most voluntarily adopted pollution reduction technologies whereas farmers with future plans to adopt precision agriculture, natural and constructed wetlands approximate $49 \%, 39 \%$ and $34 \%$ of the respondents, respectively.

\subsection{Perception of water quality and effect of regulation removal}

Based on the five likert point scale, $63 \%$ of the respondents perceive the water quality in the water bodies closest to their farms as being above average whereas a smaller percentage (3\%) perceive the quality to be low (Table 1). Farmers' perceptions on the anticipated level of negative effect on water quality in the recipient water body in case the existing regulations on some of the farm activities were removed vary greatly. However, most of the farmers (over $50 \%$ ) perceive the effect to be low or moderate in all the six scenarios presented to them as shown in Table 2 . A relatively higher percentage of respondents $(20 \%)$ indicate that removal of regulation on cover crops and winter crops could have a higher negative effect on the water quality.

Table 1: Perception of water quality in the nearest recipient water body.

\begin{tabular}{|c|c|c|c|c|c|c|}
\hline \multirow[t]{2}{*}{ Variable } & \multirow[t]{2}{*}{ Description } & \multicolumn{5}{|c|}{ Frequency (\%) } \\
\hline & & None & Low & Moderate & Good & Very good \\
\hline $\begin{array}{l}\text { Water } \\
\text { quality }\end{array}$ & $\begin{array}{l}\text { Perceived water quality in } \\
\text { the nearest water body }\end{array}$ & 5.99 & 3.37 & 27.34 & 36.33 & 26.97 \\
\hline
\end{tabular}

Table 2: Perception of the effect of regulation removal on water quality.

\begin{tabular}{|c|c|c|c|c|c|}
\hline \multirow{2}{*}{ Variable } & \multirow{2}{*}{ Description: regulation removal on:- } & \multicolumn{4}{|c|}{ Frequency $(\%)$} \\
\hline & & None & Low & Moderate & High \\
\hline Slurry & $\begin{array}{l}\text { Manure/slurry separation, spreading } \\
\text { and management }\end{array}$ & 3.00 & 53.56 & 37.08 & 6.37 \\
\hline P-feed & $\begin{array}{l}\text { Use of high phosphorous quantity in } \\
\text { animal feeds }\end{array}$ & 10.49 & 34.83 & 41.57 & 13.11 \\
\hline $\mathrm{N}$-fertilizer & Use nitrogen fertilizers & 7.49 & 57.30 & 32.21 & 3.00 \\
\hline Pesticides & Spraying of pesticides & 4.49 & 53.56 & 33.33 & 8.61 \\
\hline wwcrop & $\begin{array}{l}\text { Cultivation of winter crop/catch } \\
\text { crops }\end{array}$ & 4.87 & 37.08 & 38.20 & 19.85 \\
\hline animalU & Large animal units & 5.99 & 37.45 & 48.69 & 7.87 \\
\hline
\end{tabular}

Descriptive analysis of the farmers' subjective choice of strategies for the implementation of nutrients reduction measures shows the respondents being more supportive of the "voluntary", "subsidy" and "information dissemination" options at $76 \%, 55 \%$ and $67 \%$ respectively. A further comparison of respondents' level of 
support for implementation strategy with their current level of adoption of voluntary technologies shows respondents who have adopted at least one voluntary technology being largely in favour of "voluntary" and "information dissemination" strategies at $62 \%$ and $55 \%$ respectively. Likewise, $52 \%$ of these respondents indicate non-support for use of fines on non-compliance with the set pollution reduction regulations. The overall summary is presented in Table 3.

Table 3: Support/non-support for pollution mitigation implementation strategies.

\begin{tabular}{clccc}
\hline \multirow{2}{*}{ Variable } & Description & \multicolumn{3}{c}{ Frequency (\%) } \\
& Level of support for: & No support & Indifferent & Support \\
\hline Regulation & Fines and penalties for non-compliance & 64.04 & 18.73 & 17.23 \\
Zone & Specific rules for sensitive areas & 22.10 & 35.21 & 42.70 \\
Voluntary & Use of voluntary programs & 7.49 & 16.85 & 75.66 \\
Subsidy & Use of subsidies & 13.86 & 31.09 & 55.06 \\
Information & Information dissemination & 7.49 & 25.47 & 67.04 \\
\hline
\end{tabular}

\subsection{Empirical results}

The adoption of voluntary nutrients reduction technologies is significantly explained by the variables on farm slope, farmers' age, farmers' attitude on subsidy, farm size and farmers awareness of the existence of the constructed wetland funds. In the perception model, the physical factors are largely significant with all the variables under this classification being significant except for the distance variable. Overall, the significant variables in the perception model include soil types, farm slope, fulltime farm type and farmers' subjective reception of information on good ecological status. All the significant variables in both models display the hypothesized direction in their relationship with the dependent variables. However, the predicted adoption variable, which was expected to significantly influence farmers' perception on water quality has an insignificant effect on perception model. The empirical results showing the estimations' coefficients and marginal effects are summarized in Tables 4 and 5 .

Table 4: Results of the adoption model (ordered probit).

\begin{tabular}{lccccc}
\hline \multirow{2}{*}{ Variables } & \multirow{2}{*}{ Coefficient } & \multirow{2}{*}{ Std. Err. } & \multicolumn{3}{c}{ Average marginal effects } \\
& & & $\operatorname{Pr}\left(Y_{i}=0\right)$ & $\operatorname{Pr}\left(Y_{i}=1\right)$ & $\operatorname{Pr}\left(Y_{i}=2\right)$ \\
\hline Mid-steep slope & $0.293^{*}$ & 0.160 & -0.099 & 0.027 & 0.071 \\
Age & $0.016^{* *}$ & 0.008 & -0.005 & 0.001 & 0.004 \\
Farm size & $0.003^{* * *}$ & 0.001 & -0.001 & 0.000 & 0.001 \\
Cw funds & $-0.347^{* *}$ & 0.156 & 0.114 & -0.024 & -0.090 \\
$\mu_{1}$ & 0.650 & 0.636 & & & \\
$\mu_{2}$ & 2.047 & 0.645 & & & \\
\hline No. of observations & 267 & & & & \\
Log likelihood & -257.123 & & & & \\
LR $\chi^{2}(26$ d.f.) & $41.44^{* *}$ & & & & \\
$R^{2}$ & 0.075 & & & & \\
\hline
\end{tabular}


Table 5: Results of the perception model (ordered probit).

\begin{tabular}{lcccccc}
\hline \multirow{2}{*}{ Variable } & \multirow{2}{*}{ Coefficient } & \multirow{2}{*}{ Std. Err. } & \multicolumn{5}{c}{$\operatorname{Average~marginal~effects~}$} \\
& & & $\operatorname{Pr}\left(Y_{i}=1\right)$ & $\operatorname{Pr}\left(Y_{i}=2\right)$ & $\operatorname{Pr}\left(Y_{i}=3\right)$ & $\operatorname{Pr}\left(Y_{i}=4\right)$ \\
\hline Sand & $-0.248^{*}$ & 0.149 & 0.037 & 0.047 & -0.010 & -0.074 \\
Heavy-clay & $0.289^{*}$ & 0.167 & -0.039 & -0.056 & 0.007 & 0.089 \\
Mid-steep slope & $-0.298^{*}$ & 0.175 & 0.039 & 0.060 & -0.005 & -0.094 \\
Steep slope & $-0.955^{* * *}$ & 0.286 & 0.185 & 0.1500 & -0.092 & -0.243 \\
Farmtype3 & $-0.355^{*}$ & 0.184 & 0.048 & 0.068 & -0.007 & -0.110 \\
GES info & $0.407^{* *}$ & 0.176 & -0.054 & -0.081 & 0.006 & 0.128 \\
$\mu_{1}$ & -0.759 & 0.719 & & & & \\
$\mu_{2}$ & 0.334 & 0.717 & & & & \\
$\mu_{3}$ & 1.394 & 0.719 & & & & \\
\hline No. of & 267 & & & & & \\
observations & -320.235 & & & & & \\
Log likelihood & $52.44^{* * *}$ & & & & & \\
LR $\chi^{2}$ (26 d.f.) & 0.076 & & & & & \\
$R^{2}$ & & & & & & \\
\hline
\end{tabular}

\section{Discussion}

Adoption of one or more voluntary agri-environmental technologies is seen to be highly related to farm size (Table 4). This corresponds to other adoption studies $[26,27]$ where farmers with larger farms are more likely to adopt technologies and schemes that may leave out part of the farms out of production. Older farmers are more likely to adopt more technologies, a finding which contrasts other adoption studies [26, 28]. These studies cite risks and costs as the main factor for low adoption among older farmers and younger farmers, respectively. The widely adopted technologies in this study (natural wetlands and permanent grass cultivation) could however be associated with low risks. Farmers with mid-steep sloped farms have a 0.071 probability of implementing more technologies compared to those with farms on a flat elevation. Unexpectedly, the farmers indicating unawareness of funds for construction of wetlands show a higher adoption rate. This could indicate a strong individual motivation in adoption of the technology, and could be supported through increased information dissemination of the existing incentives associated with adoption of agri-environmental technologies [9]. Additionally, respondents supporting use of subsidies as a strategy for implementing nutrient reduction measures are more likely to adopt more than two technologies by 0.099 .

The results of perceived water quality in the descriptive analysis closely follow the reported quality of water in Danish coastal and inland bathing sites in 2012 [29] with only $3.1 \%$ of the sampled sites being rated poor. The perception of farmers on the would-be effect on water quality in the event that the regulations are relaxed also rhyme with previous studies in water quality management [11, 15]. The outcome of the perception model shows respondents with portions of sandy soil in their farms being less likely to perceive high water quality and viceversa for respondents with farms with heavy-clay portions. These results are in line with Schjønning et al. [30], who report that clay content in the soil increases water infiltration into the soils thereby reducing the level of surface 
run-off. The analysis consequently shows farmers with mid-steep and steep sloped farms being more likely to perceive low water quality. The overall general significance of the physical factors in the perception model could be an implication of farmers' intrinsic awareness of the different soil properties and farm slopes and their influence on agricultural discharge movement and nutrients transportation through the runoff. This awareness could have further played a key role in forming their attitudes on water quality. Farm characteristics such as slope and soil type and structure have been cited as key factors contributing to diffuse water pollution [31].

The dummy variable for fulltime farmers indicates a negative relationship this variable and farmers perception of water quality. The full-time farmers could be innately aware of the intensity of their farming activities and the likelihood of such activities leading to pollution of water bodies by discharges from the farms.

The positive and significance variable on the variable farmers' subjective reception of information on good ecological status (GES) means farmers with information are more likely to perceiving the water quality being high. Unpredictably, only $30 \%$ of the respondents indicate having received this information. This is an indication of an information gap which could be as a result of centralized system in Denmark [32]. This calls for improvement of information dissemination processes [16].

The predicted variable on adoption of voluntary nutrient reduction technologies shows an insignificant relationship with perception. This difference with the priori may have resulted from the fact that some of the technologies adopted by the farmers have multiple benefits thus yielding different utilities to the adopters. Practicing precision farming is one such example where farmers may employ site specific fertilizer and pesticide applications thereby reducing the variable production costs in addition to reduction of excess nutrient that may end up in farm discharge.

\section{Conclusions and policy implications}

Understanding farmers' decisions on adoption of voluntary nutrients pollution mitigating technologies and their inherent attitudes and perceptions regarding water quality and the existing regulatory measures are key starting points to consider when designing and providing options for farmers to implement measures that reduce pollution from agricultural fields. This study has analyzed these aspects in the pursuit of identifying the critical aspects to be considered in the future design of implementing the constructed wetland measure among the Danish farmers.

The study finds that majority of the farmers perceive the quality of water in the fjords and lakes draining from their farms to be above average. Consequently, the farmers feel that changes that would lead to removal of the regulatory measures would have little or no impact in lowering the water quality. This perception may however be misinformed since majority of the farmers have not had access to full information on the underlying stipulations and requirements of "good ecological status" under the water framework directive. The study also finds that farmers have 
a general negative attitude towards regulatory nutrient reduction measures despite a relatively large number of these farmers having implemented voluntary environmental measures. Adoption of voluntary technologies is influenced by farmers' age and farm size among other factors. Additionally, other factors such as farm type, soil types, farm slope and awareness of GES requirements are seen to play a key role influencing farmers' perceptions and need to be fully considered in the implementation design of the more targeted pollution reduction measures.

To bridge the identified information gap, a collaborative effort between policy makers and the various stakeholders to decentralize information should be pursued. This will ensure a smooth and efficient flow of information thereby improving on measure compliance and water quality target achievements. Whereas the regulatory measures still remain in place, designing of tailor-made incentives based on farm structure and physical characteristics would greatly improve the pace of adoption of the technologies thereby reducing water pollution substantially.

\section{Appendix 1: Description of variables $(\mathrm{N}=267)$}

\begin{tabular}{|c|c|c|c|c|c|}
\hline \multirow{2}{*}{$\begin{array}{c}\text { Dependant } \\
\text { variables }\end{array}$} & \multirow[t]{2}{*}{ Variable description } & \multirow[t]{2}{*}{ Mean } & \multirow[t]{2}{*}{ Std. Dev. } & \multicolumn{2}{|c|}{ Expected sign } \\
\hline & & & & Techadopt & Wqltypercp \\
\hline Techadopt & Voluntary technologies adoption level & 0.899 & 0.850 & & \\
\hline Wqltyperc & Perceived water quality & 3.750 & 1.076 & & \\
\hline \multicolumn{6}{|c|}{ Explanatory variables } \\
\hline \multicolumn{6}{|c|}{ Exogenous water quality variables/physical factors } \\
\hline Distance & $\begin{array}{l}\text { If farm is located less than } 14 \mathrm{~km} \text { (average } \\
\text { sample distance) from the nearest recipient water } \\
\text { body }(0=\text { no, } 1=\text { yes })\end{array}$ & 0.374 & 0.485 & + & + \\
\hline Sand & Sandy soil type dummy $(0=$ no, $1=$ yes $)$ & 0.494 & 0.501 & + & - \\
\hline Heavy-clay & Heavy clay soil type dummy ( $0=$ no, $1=$ yes $)$ & 0.259 & 0.439 & - & + \\
\hline Slope & $\begin{array}{l}\text { Slope of respondent's farm: categorical variable } \\
\text { ( } 3 \text { levels: } 1=\text { =Flat, } 2=\text { Mid-steep, } 3=\text { Steep) }\end{array}$ & 1.719 & 0.594 & $+/-$ & $+/-$ \\
\hline Fjord & $\begin{array}{l}\text { Recipient water body closest to the respondents } \\
\text { farm ( } 1=\text { Hjarbæk, } 2=\text { Kattagat, } \\
3=\text { Limfjorden, } 4=\text { Mariager } 5=\text { Others })\end{array}$ & 3.382 & 1.129 & $+/-$ & na \\
\hline Pipedrain & $\begin{array}{l}\text { If the farm is drained through pipes }(0=\text { no, } \\
1=\text { yes })\end{array}$ & 0.813 & 0.391 & $+/-$ & na \\
\hline \multicolumn{6}{|c|}{ Personal and attitudinal factors } \\
\hline Age & Farmer's age (year) & 51.430 & 10.005 & $+/-$ & $+/-$ \\
\hline Regulation & $\begin{array}{l}\text { Farmers attitude on fines and penalties for non- } \\
\text { compliance as a nutrient reduction strategy ( } 3 \\
\text { categories: } 1=\text { Non-support, } 2=\text { =Indifferent, } \\
3=\text { Support) }\end{array}$ & 1.532 & 0.772 & - & $+/-$ \\
\hline Subsidy & $\begin{array}{l}\text { Farmers attitude on subsidy support as a nutrient } \\
\text { reduction strategy ( } 3 \text { categories: } 1=\text { =Non-support, } \\
2=\text { =ndifferent, } 3=\text { Support) }\end{array}$ & 2.411 & 0.722 & + & $+/-$ \\
\hline
\end{tabular}


Appendix 1 Continued.

\begin{tabular}{|c|c|c|c|c|c|}
\hline $\begin{array}{l}\text { Dependant } \\
\text { variables }\end{array}$ & Variable description & Mean & Std. Dev. & \multicolumn{2}{|c|}{ Expected sign } \\
\hline Voluntary & $\begin{array}{l}\text { Farmers' attitude on voluntary option as a } \\
\text { nutrient reduction strategy ( } 3 \text { categories; } 1=\text { Non- } \\
\text { support, } 2=\text { =Indifferent, } 3=\text { Support) }\end{array}$ & 2.862 & 0.606 & + & $+/-$ \\
\hline Nfertilizer & $\begin{array}{l}\text { Perceived effect on water quality if regulation on } \\
\text { fertilizer usage is removed ( } 1=\text { none, } 2=\text { low, } \\
3=\text { moderate, } 4=\text { high) }\end{array}$ & 2.307 & 0.651 & na & $+/-$ \\
\hline Animal unit & $\begin{array}{l}\text { Perceived effect on water quality if regulation on } \\
\text { animal unit is removed (1=none, } 2=\text { low, } \\
3=\text { moderate, } 4=\text { high })\end{array}$ & 2.582 & 0.723 & na & $+/-$ \\
\hline \multicolumn{6}{|c|}{ Economic factors } \\
\hline Farm type 1 & $\begin{array}{l}\text { Farm types }(1=\text { crop, } 2=\text { crop/cattle, } 3=\text { crop/pig; } \\
4=\text { others })\end{array}$ & 2.207 & 0.944 & $+/-$ & na \\
\hline Farm size & Size of the farm (hectares) & 143.440 & 119.452 & + & - \\
\hline Farm type 3 & Full time farm-type dummy ( $0=$ no, $1=$ yes $)$ & 0.723 & 0.448 & - & + \\
\hline Logtuover & Log of turnover averaged over farm-size & 0.227 & 0.338 & + & na \\
\hline \multicolumn{6}{|c|}{ Institutional factors } \\
\hline GES info & $\begin{array}{l}\text { Subjective farmers reception of information on } \\
\text { ecological status information (dummy: } 0=\text { no, } \\
1=\text { yes) }\end{array}$ & 0.300 & 0.459 & + & + \\
\hline NP info & $\begin{array}{l}\text { Subjective farmers reception of information on } \\
\text { Nitrogen and Phosphorous reduction measures } \\
\text { (dummy: } 0=\text { no, } 1=\text { yes) }\end{array}$ & 0.333 & 0.472 & + & + \\
\hline$C w$ funds & $\begin{array}{l}\text { Farmers awareness of the constructed wetlands } \\
\text { funding }\end{array}$ & 0.667 & 0.472 & $+/-$ & na \\
\hline
\end{tabular}

\section{References}

[1] Smith, R. J. N., Glegg, G. A., Parkinson, R., \& Richards, J. P., Evaluating the implementation of the Nitrates Directive in Denmark and England using an actor-orientated approach. European environment, 17(2), pp. 124-144, 2007.

[2] www.mst.dk, Accessed August 2013.

[3] http://www.statbank.dk/statbank5a/default.asp?w=1920/ accessed September, 2013.

[4] Jacobsen, B. H., Laugesen, F. M., Dubgaard, A., \& Bojesen, M. Biogasproduktion i Danmark-Vurderinger af drifts-og samfundsøkonomi Institut for Fødevare-og Ressourceøkonomi, Københavns Universitet, Frederiksberg. IFRO Rapport, no. 220, 2013.

[5] http://fvm.dk/biomasse. Accessed May 30th 2013.

[6] Kjærgaard, C., Canga, E., Heckrath, G. J., Iversen, B. V., Hoffmann, C. C., Druenhahl, J. B., Nielsen, P., Gertz, F., Lyngsie, G., Strobel, B., Borggaard, O., \& Hansen, H. C. B., Drainage filters and constructed wetlands to mitigate site specific nutrient losses. In Proceedings from the 7th SWS 2012, European chapter meeting, 2012.

[7] Kjaergaard, C. \& Hoffmann, C.C., 2013. Konstruerede vådområder til målrettet reduktion af næringsstoffer i drænvand, No. 61202, 33, 2013. 
[8] Lichtenberg, E., \& Lessley, B. V., Water quality, cost-sharing, and technical assistance: perceptions of Maryland farmers. Journal of soil and water conservation, 47(3), pp. 260-264, 1992.

[9] Ryan, R. L., Erickson, D. L., \& De Young, R., Farmers' motivations for adopting conservation practices along riparian zones in a mid-western agricultural watershed. Journal of Environmental Planning and Management, 46(1), pp. 19-37, 2003.

[10] Morton, L. W., A different view: Mid-West farmers' perceptions of water quality. In annual meeting of the Rural Sociological Society, Marriott Santa Clara, Santa Clara, California (Vol. 3), 2007.

[11] Popp, J., Rodriguez, G., Gbur, E., \& Pennington, J., The role of stakeholders' perceptions in addressing water quality disputes in an embattled watershed. Journal of environmental monitoring and restoration, 3, pp. 225-263, 2007.

[12] Bratt, A., Farmers' choices: Management practices to reduce nutrient leakage within a Swedish catchment. Journal of environmental planning and management, 45(5), pp. 673-689, 2002.

[13] Sang, N., Informing common pool resource problems: A survey of preference for catchment management strategies amongst farmers and the general public in the Ythan river catchment. Journal of environmental management, 88(4), pp. 1161-1174, 2008.

[14] Macgregor, C. J., \& Warren, C. R., Adopting sustainable farm management practices within a Nitrate Vulnerable Zone in Scotland: The view from the farm. Agriculture, ecosystems \& environment, 113(1), pp. 108-119, 2006.

[15] Barnes, A. P., Willock, J., Hall, C., \& Toma, L., Farmer perspectives and practices regarding water pollution control programmes in Scotland. Agricultural water management, 96(12), pp. 1715-1722, 2009.

[16] Atkins, J. P., \& Burdon, D., An initial economic evaluation of water quality improvements in the Randers Fjord, Denmark. Marine pollution bulletin, 53(1), pp. 195-204, 2006.

[17] Christensen, T., Pedersen, A. B., Nielsen, H. O., Mørkbak, M. R., Hasler, B., \& Denver, S., Determinants of farmers' willingness to participate in subsidy schemes for pesticide-free buffer zones - a choice experiment study. Ecological economics, 70(8), pp. 1558-1564, 2011.

[18] Ervin, C. A., \& Ervin, D. E., Factors affecting the use of soil conservation practices: hypotheses, evidence, and policy implications. Land economics, 58(3), pp. 277-292, 1982.

[19] Just, R. E., \& Zilberman, D., Stochastic structure, farm size and technology adoption in developing agriculture. Oxford Economic Papers, pp. 307-328, 1983.

[20] Kabii, T., \& Horwitz, P., A review of landholder motivations and determinants for participation in conservation covenanting programmes. Environmental Conservation, 33(01), pp. 11-20, 2006.

[21] Knowler, D., \& Bradshaw, B., Farmers' adoption of conservation agriculture: A review and synthesis of recent research. Food policy, 32(1), pp. 25-48, 2007. 
[22] Fishbein, M., \& Ajzen, I., Belief, attitude, intention and behavior: An introduction to theory and research, 1975.

[23] Ajzen, I., From intentions to actions: A theory of planned behaviour, Springer Berlin Heidelberg, pp. 11-39, 1985.

[24] Wauters, E., Bielders, C., Poesen, J., Govers, G., \& Mathijs, E., Adoption of soil conservation practices in Belgium: an examination of the theory of planned behaviour in the agri-environmental domain. Land Use Policy, 27(1), pp. 86-94, 2010.

[25] Greene, W.H. Econometrics Analysis. Upper Saddle River, New Jersey, 2008.

[26] Hodge, I., \& Reader, M., The introduction of Entry Level Stewardship in England: Extension or dilution in agri-environment policy? Land Use Policy, 27(2), pp. 270-282, 2010.

[27] Ma, S., Swinton, S. M., Lupi, F., \& Jolejole-Foreman, C., Farmers' Willingness to Participate in Payment-for-Environmental-Services Programmes. Journal of Agricultural Economics, 63(3), pp. 604-626, 2012.

[28] Giovanopoulou, E., Nastis, S. A., \& Papanagiotou, E., Modeling farmer participation in agri-environmental nitrate pollution reducing schemes. Ecological economics, 70(11), pp. 2175-2180, 2011.

[29] European Environmental Agency, European bathing water quality in 2012, EEA Report No 4/2013.

[30] Schjønning, P., Heckrath, G., \& Christensen, B. T., Threats to soil quality in Denmark: A review of existing knowledge in the context of the EU Soil Thematic Strategy. Aarhus Universitet, Det Jordbrugsvidenskabelige Fakultet, 2009.

[31] Collins, A. L., Strőmqvist, J., Davison, P. S., \& Lord, E. I., Appraisal of phosphorus and sediment transfer in three pilot areas identified for the catchment sensitive farming initiative in England: application of the prototype PSYCHIC model. Soil Use and Management, 23(s1), pp. 117132, 2007.

[32] Prager, K., Schuler, J., Helming, K., Zander, P., Ratinger, T., \& Hagedorn, K., Soil degradation, farming practices, institutions and policy responses: An analytical framework. Land degradation \& development, 22(1), pp. 3246, 2011. 